\title{
Herodian and the Crisis of Emperorship, A.D. 235-238
}

\author{
Caillan Davenport \\ Macquarie University \\ caillan.davenport@mq.edu.au \\ Christopher Mallan \\ University of Western Australia \\ christopher.mallan@uwa.edu.au
}

\begin{abstract}
This article examines Herodian's portrayal of the rise and fall of Roman emperors and usurpers in Books VII and VIII of his History (covering the years A.D. 235-238). Herodian's narrative provides its readers with a perceptive account of the challenges faced by Rome's rulers during the middle decades of the third century A.D. Emperors had to defend the frontiers while cultivating the support of the army, the senate, and the people of Rome and the provinces. The historian explores how potential candidates for the purple were likely to succeed or fail based on the support, or lack thereof, of these key constituencies. He shows how even theoretically promising experiments in imperial rule, such as the joint reign of Pupienus and Balbinus, were ultimately doomed to fail because the emperors did not possess a deep and broad consensus among all elements of the Roman state.
\end{abstract}

\section{Keywords}

Herodian - Maximinus - Gordian I - Pupienus - Third Century A.D. - Roman historiography

\section{$1 \quad$ Introduction}

Herodian's History of the Empire after Marcus, written in the middle decades of the third century, ${ }^{1}$ is a tightly-presented narrative structured around a central theme: the failure of

\footnotetext{
${ }^{1}$ Most scholars place Herodian in the reign of Philip or Decius: Whittaker 1969-70, 1.xiixix; Alföldy 1971a, 218-219; 1971b, 431; Marasco 1998, 2839; Zimmermann, 1999, 285302; Polley 2003, 203-208; Kemezis 2014, 300-304; Galimberti 2014,10. Cf. Sidebottom
} 
the succession of imperial claimants in the period between 180-238. ${ }^{2}$ For Herodian, this stemmed from the fact that all emperors, or potential emperors, fell short of the model rule of Marcus Aurelius. ${ }^{3}$ Under the exemplary Marcus, the state was in perfect balance because of the eưvoıa and ómóvoı fostered by the philosopher emperor. ${ }^{4}$ The failures of Marcus' successors were not necessarily the result of their personal and moral shortcomings; instead they were defeated by a lack of harmony between, and the loss of the support of, the constituent elements of the state - the army, the Senate, and the people of Rome and the provinces. ${ }^{5}$ Of course, Herodian's analysis goes beyond these superficial abstractions. Herodian's history exposes numerous problems in Roman imperial government, such as the ambitions of courtiers and the unstable position of young emperors. ${ }^{6}$ Such points of focus speak volumes about Herodian's overarching conception of the imperial office as an essentially fragile institution based on a precarious balancing act, composed of general as well as particular factors. ${ }^{7}$

Given his interest in the turnover of Roman emperors, signalled in the preface to Book 1, it is not surprising that Herodian offers a detailed account of the years 235-238,

1997, 271-276, who proposes the reign of Gallienus. It should be noted that no serious arguments preclude production in the reign of Gordian III: Kaldellis 2017, 51-52. References to Herodian are taken from the Teubner edition. All translations are our own.

${ }^{2}$ Hdn. 1.1.4-6; Whittaker, 1969-70, 1.xli-xliii; Alföldy 1971b, 434; Kemezis 2014, 235237; Hidber 2006, 124-187.

${ }^{3}$ Marasco 19987, 2840-2857 and Hidber 2006, 188-272 present extensive analyses of Herodian's view of Marcus and his successors. See also, inter alia, de Blois 1998, 3416; Sidebottom 1998, 2804-2805; Kuhn-Chen 2002, 324-327; Kemezis 2014, 240. For the title of Herodian's work, see Lucarini 2005, ix n. 1.

${ }^{4}$ There was universal mourning of the army and people at Marcus' passing (Hdn. 1.4.8), followed by the breakdown of these relationships in the aftermath, as several scholars have noted: Alföldy 1971b, 435; de Blois 1998, 3416; Marasco 1998, 2841.

${ }^{5}$ The balance of army, senate, people, and the security of the frontiers is brought out in the speech of Pompeianus to Commodus: Hdn. 1.6.6, with Marasco 1998, 2841.

${ }^{6}$ Note, for example, Hidber 2006, 181-186 on the similarities in Herodian's 'Machtwechselgeschichten'. For the young emperors, see Hdn. 1.3.1-5; Marasco, 1998, 2844; Hidber 2006, 243-272.

${ }^{7}$ It is worth noting that the style and the themes of Herodian's work differ significantly from the Roman History of Cassius Dio. Dio's rich and polychromatic annalistic history, embellished with abundant prosopographical detail, discusses the vicissitudes of the senatorial aristocracy of the Antonine and Severan periods in a way that Herodian does not. 
which form the subject of Books VII and VIII. ${ }^{8}$ This period saw the murder of Severus Alexander, the reign of Maximinus, and the infamous year of the six emperors in 238 . Books VII and VIII are therefore dominated by a series of revolts, which are either instigated by the would-be emperors themselves, or forced upon them by outsiders, such as the army or the people. ${ }^{9}$ This article offers a detailed examination of how Herodian presents the period 235-238, and how his account feeds into his overarching conception of the crisis of emperorship which forms the theme of his work. Part I examines Herodian's depiction of the procession of emperors and usurpers in the period 235-238. As we shall see, Herodian's presentation of these short-lived regimes is developed in such a way as to anticipate their inevitable failures. Part II turns to the final speech in Herodian's history, that of the emperor Pupienus outside Aquileia. It analyses how the speech presents a model for imperial rule in the post-Severan world. However, like many of Herodian's speeches, Pupienus' oration is undermined by a deep ironic undercurrent. ${ }^{10}$ The speech, therefore, serves to foreshadow the impending collapse of the double monarchy of Pupienus and Balbinus, while also raising questions about the practicality of any such model if the emperor, or emperors, lacked the support of the army.

\section{Emperors and Pseudo-Emperors}

In Herodian's worldview, Roman emperors depended on consensus and concord (ópóvoıa), and the need to establish good relationships with the senate and the people (in the provinces and in the city of Rome), as well as the different groups within the Roman army (such as the praetorian guard, urban cohorts, legions and auxiliary forces). ${ }^{11} \mathrm{He}$ attached special importance to the legitimacy conferred by the city of Rome and its

\footnotetext{
${ }^{8}$ Hdn. 1.1.5.

${ }^{9}$ Hidber 2006, 174.

${ }^{10}$ For the ironic qualities of Herodian's speeches, see Sidebottom 1998, 2817-2818; Kemezis 2014, 252 .

${ }^{11}$ For ómóvola in Greco-Roman thought, see Barker 1956, 190-192, 359-60; Lotz 2007: 66-87.
} 
institutions. ${ }^{12}$ But Herodian also recognised that this had to be balanced with the need to defend the empire in person on the frontiers. This situation had first become apparent in the reign of Marcus Aurelius, but had intensified by the reign of Severus Alexander, who was summoned twice to the frontiers from Rome by his governors. ${ }^{13}$ Herodian's insistence on his emperors' need to balance these competing priorities, especially the city of Rome with the frontiers, is a unique and important insight into third-century emperorship from a contemporary author. ${ }^{14}$

Book VII begins with Maximinus already installed as emperor after his coup against Severus Alexander. The opening has a programmatic feel, couched in the familiar terms of metabole politeion, as Herodian tells his readers that Maximinus' aim was to change the government 'from a mild and very civilized kingship to a cruel tyranny' (हैk T $\tau$

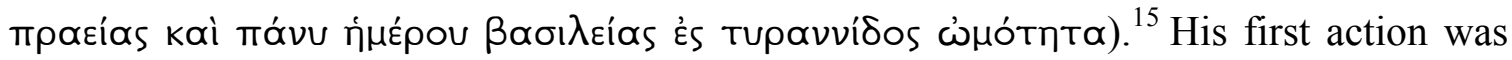
therefore to remove his predecessor's associates from the imperial consilium. Herodian's presentation of this change is designed to cast doubt on the longevity of Maximinus' regime from the beginning. Maximinus' dismissal of the consilium is presented as a rejection of the senate, a response to his fear of the curia and the nobility in general. $\mathrm{He}$ sends the consilium back to Rome so he could be left alone with the army, without anyone of noble birth to overshadow him. ${ }^{16}$ This action directly contrasts with the model of good imperial government advocated by the senatorial grandee Ti. Claudius Pompeianus, friend and advisor to Marcus Aurelius, in Book I. There, Pompeianus' speech to Marcus' son Commodus advises the young emperor that it would be possible for him to remain on the frontiers and to govern Rome while on campaign, so long as he is prepared to have both the senate and the army at his side. ${ }^{17}$ Therefore, when

\footnotetext{
12 Pitcher 2012, 273-274, on the need for Herodian's emperors to be in Rome. On the tension between centre and periphery on Herodian's work, see the acute analysis of Kemezis 2014, 239-252.

${ }^{13}$ Hdn. 6.3.1, 6.7.3.

${ }^{14}$ See now Davenport 2017, 26-27. There is no such imperative in the work of Dio, where the stress is more on the concord between the emperor and his senators.

${ }^{15}$ Hdn. 7.1.1. Whittaker 1969-70, 2.149 n. 2; Martin 2006. cf. Mecella 2017.

${ }^{16} \mathrm{Hdn}$. 7.1.3. This of course is an interpretation of the consilium which lacks nuance - its members are noble senators, and no equestrian officials are mentioned (see the comments of Zimmermann 1999, 263).

${ }^{17}$ Hdn. 1.6.6 with Galimberti 2014, 43-44.
} 
Maximinus dismisses the senatorial advisors, he rejects this paradigm of Marcus Aurelius' good government. His reign is not only destined to become a tyranny, it is also doomed to failure.

The plots hatched against Maximinus while he is in Germany are used by Herodian to demonstrate the emperor's poor choices. ${ }^{18}$ The first rival claimant to the throne is a certain Magnus, who is both a patrician and an ex-consul. These details are included by Herodian to underscore the difference between him and Maximinus. ${ }^{19}$ Magnus hatches a plan to destroy the bridge across the Rhine and leave Maximinus stranded on the other side, but he and his co-conspirators are caught and executed before they can carry out their designs. ${ }^{20}$ The second insurrection involves Quartinus, who, so Herodian relates, was one of the recently dismissed consular amici of Severus Alexander. ${ }^{21}$ Quartinus is proclaimed emperor by the Osrhoenian archers who were fiercely loyal to Alexander and resented his death. Although an unwilling candidate for the throne, Quartinus proves unable to resist their efforts to make him emperor, which would be the fate of many generals in the middle decades of the third century. ${ }^{22}$ In a tale almost humorous in its tragedy, Quartinus is fitted out with the imperial purple and the ceremonial torch. Herodian ironically describes these as 'deadly honours' (ỏ $\lambda \varepsilon \theta$ píoss тıкоĩs), a turn of phrase which neatly encapsulates the predicament such usurpers faced. Indeed, Quartinus is soon murdered in his sleep by Macedo, the leader of the Osrhoenian archers who proclaimed him. ${ }^{23}$ Macedo proceeds to offer Maximinus the head of the

\footnotetext{
${ }^{18}$ For an examination of these revolts, see Haegemans 2010, 93-96. Zimmermann 1999, 256-260 argues that the revolts are not believable as historical events. However, that does not undermine our analysis, which concentrates on Herodian's portrayal of the usurpations, rather than their historical credibility.

${ }^{19}$ Hdn. 7.1.5. It has been suggested Magnus should be identified with C. Petronius Magnus who features in the Album of Canusium (CIL IX $338=I L S$ 6121; Whittaker 1969-70, 2.152-3). Cf. the caution of Dietz 1980, 188.

${ }^{20} \mathrm{Hdn}$. 7.1.5-8. The $H A$ tells the same story, relying directly on Herodian's account $(H A$ Max. 10.1-4).

${ }^{21}$ Hdn. 7.1.9. He is given the name Titus by the HA (Max. 11.2; Trig. Tyr. 32.1).

${ }^{22}$ Note the examples of Decius, who was sent by Philip to suppress the revolt of Pacatianus, only to be acclaimed emperor himself (Zos. 1.21-22), and Aemilius Aemilianus, acclaimed for his success against the Goths by the army under his command (Zos. 1.28, cf. Aur. Vict. Caes. 31.1, who says he manufactured his acclamation).

${ }^{23} \mathrm{Hdn}$. 7.1.10. He is called Macedonius by the HA (Max. 11.4).
} 
hapless Quartinus, only for the emperor to execute him in turn. The story serves a larger narrative purpose of hardening Maximinus' nature, further setting him on the road to tyranny. ${ }^{24}$

It is striking that Herodian's account of these usurpations against Maximinus features no less than three named actors: Magnus, Quartinus, and Macedo. This is a dramatic contrast to the dearth of prosopography in Herodian's narrative of the reign of Severus Alexander in Book VI, which telescopes the emperor's years in Rome (222-229) into a single chapter, and where no one outside of the imperial family is named explicitly. ${ }^{25}$ Indeed, Herodian's History as a whole is notoriously light on prosopographical detail, even when he clearly knows the names and identities of individuals to whom he refers obliquely. ${ }^{26}$ But the vicissitudes of senatorial and court life in Rome, which Cassius Dio recounts with exactness in his account of the earlier Severan emperors, were of no interest to Herodian. ${ }^{27}$ Instead, he only employs prosopographical details as and when necessary to illuminate his key narrative set pieces, especially those devoted to the turnover of emperors. The series of named usurpers at the beginning of Book VII is designed to reveal Maximinus' precarious hold on power by showing that his opponents are real individuals, not anonymous cyphers. Maximinus fails to win over the senate, and thus he faces a series of revolts, as his reign descends into tyranny. But the senatorial rivals are not successful either, brought down by the fickleness of the soldiers who could make and break emperors. The end result is a narrative that offers no answers, and thus is almost nihilistic in its catalogue of imperial failures, each precipitated by different factors.

\footnotetext{
${ }^{24}$ Hdn. 7.1.11; Zimmermann 1999, 258-259.

${ }^{25}$ The lack of prosopographical detail here has been noted by Syme 1971, 146-147; Sidebottom 1998, 2790.

${ }^{26}$ For example, the names of Caracalla's wife (Hdn. 3.10.5), Elagabalus' associates (Hdn. 5.7.6-7), and Severus Alexander's wife and her father (Hdn. 6.1.9-10). See the catalogue of named figures in the work in Sidebottom 1998, 2790-2791.

${ }^{27}$ On this difference between Dio and Herodian, see Kemezis 2014, 236-237. Herodian was almost certainly not a senator, or at any rate did not portray himself as a senatorial insider like Dio, though it is difficult to determine his precise social status, or even provincial origin: Hidber 2004; Kemezis 2014, 304-308. It is not necessary to see him as a freedman: cf. Alföldy 1971a.
} 
The next significant narrative set piece featuring rival emperors takes place in Africa three years later, in $238 .^{28}$ This is the scene for the acclamation of the elderly proconsul of Africa M. Antonius Gordianus Sempronianus Romanus Africanus (henceforth Gordian) by the band of youths who revolted in response to the harsh tax exactions of Maximinus and his officials. ${ }^{29}$ Herodian gives Gordian a detailed introduction that outlines his qualifications for the throne, most notably his nobility

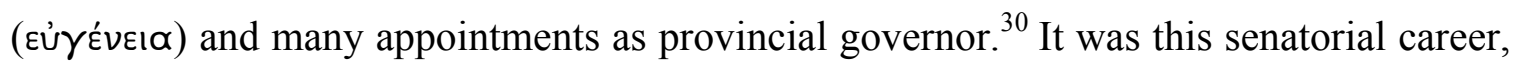
Herodian says, that made him amenable as emperor to both the senate and people of Rome. This comment reflects the endurance into the 240s of traditional conceptions of emperorship, which were unaltered by the accession of men from the equestrian order such as Macrinus and Maximinus. ${ }^{31}$ Gordian's senatorial career stands in stark contrast to Maximinus' rather more rapid, and at this time still unconventional, elevation from the ranks of army officers. ${ }^{32}$ When Gordian is proclaimed emperor by the turbulent group of veavíøKol, one of their number delivers a speech in which he echoes the views already expressed by Herodian himself: Maximinus is a tyrant, and Gordian's official career and status makes him a suitable emperor. ${ }^{33}$ The fact that the youth is not named is important, as it does not connect the sentiments of the speech to any particular individual, but gives them a universal quality and relevance. Gordian's senatorial background and illustrious career theoretically qualify him for imperial rule.

Herodian is concerned to show why such a capable and qualified man failed as emperor. Firstly, Gordian's acclamation certainly has a rather pathetic quality about it. He is unwillingly clothed in purple by the youths while lying on a couch in his villa at

${ }^{28}$ Herodian devotes little serious attention to the administration or politics under Maximinus, preferring to concentrate on his oppressive and tyrannical nature (see Hidber 2006, 149).

${ }^{29}$ The historical events are analyzed by Townsend 1955; Haegemans 2010, 131-160.

${ }^{30}$ Hdn. 7.5.2. For Gordian's background and career, see Grasby 1975, 123-130; Birley 2005, 338-341; Dietz 1999, 56-73.

${ }^{31}$ Senators, many of consular or patrician families, are well-attested as governors of provinces with legions into the middle decades of the third century. See Syme 1983, 346, 356; Heil 2006, 421-422.

${ }^{32}$ Maximinus was probably an equestrian officer at the time of his elevation (Syme 1971, 185-188).

${ }^{33} \mathrm{Hdn}$. 7.5.5. 
Thysdrus, and is forced to accept the empire at the point of the sword. ${ }^{34}$ The image of the recumbent elderly imperial candidate acclaimed by a group of young men suggests an inversion of the proper order of things - young men surely have no authority to crown anybody. ${ }^{35}$ Moreover, the scene perhaps recalls the way in which Pertinax was acclaimed, sitting at his couch at home, thinking Laetus and Eclectus had come to murder him. ${ }^{36}$ But there is more to be said. Herodian's shifts in focalisation combine to produce an evocative image of imperial politics in the 230s. Gordian, although he secretly did want to become emperor, ${ }^{37}$ was also motivated by the fact that 'he preferred to choose

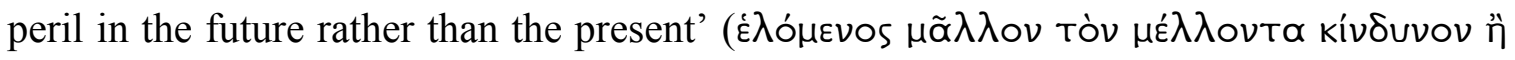

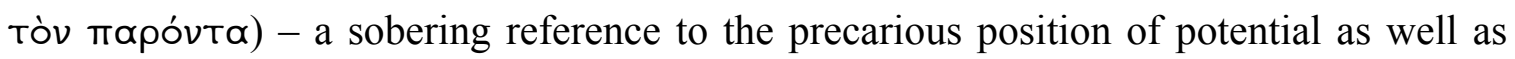
actual emperors. ${ }^{38}$ More importantly, Herodian had earlier attributed exactly the same motivation to Maximinus himself, when the soldiers responded to his recusatio imperii by threatening to kill him. ${ }^{39}$ In having Gordian express the same fears as the very emperor he was revolting against, Herodian underlines the unstable nature of imperial power, while also narrowing the differences between a military upstart like Maximinus and an elderly senator such as Gordian. It is an inauspicious beginning to the reign of Gordian. Although Maximinus is unquestionably a bad ruler in Herodian's eyes, the author does not necessarily endorse the imperial pretensions of Gordian. ${ }^{40}$

The second harbinger of doom is that Gordian does not travel to Rome immediately in order to assert his legitimacy - something that Herodian considers a sine qua non for a new emperor. ${ }^{41}$ Instead, he goes to Carthage to establish his regime, 'so

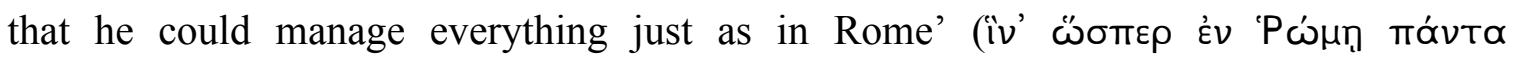
трó(Tol). ${ }^{42}$ Gordian parades about the city with the youth acting as his praetorian guard,

\footnotetext{
${ }^{34}$ Hdn. 7.5.3-4.

${ }^{35}$ It is a commonplace of ancient (and modern) literature that young men are prone to rashness and revolutionary designs (Laes and Strubbe 2014, 42-48).

${ }^{36}$ Hdn. 2.1.6. The parallels are noted by Opelt 1998, 2949; Zimmermann 1999, 274; Hidber 2006, 186.

${ }^{37}$ Gordian was performing the recusatio imperii here (Haegemans 2010, 147-148).

${ }^{38} \mathrm{Hdn}$. 7.5.6.

${ }^{39} \mathrm{Hdn}$. 6.8.6.

${ }^{40}$ Haegemans 2010, 152-153.

${ }^{41}$ Pitcher 2012, 273-274.

${ }^{42}$ Hdn. 7.6.1.
} 
his proconsular fasces are decorated with laurel, and he has the ceremonial fire carried

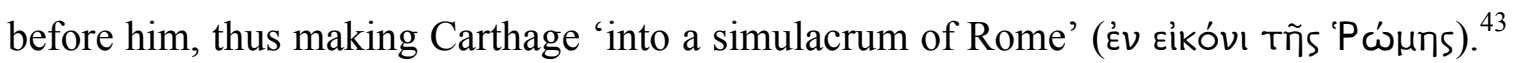
The reader of Herodian's History would probably realise that such an attempt to recreate Rome in the provinces would be hopeless, as evidenced by the failure of both Pescennius Niger and Macrinus to rule successfully from Antioch for any length of time. ${ }^{44}$ The same idea recurs in Maximinus' own speech to the army at Sirmium, in which he outlines the futility of Gordian's revolt. He mocks Gordian's imperial processions, as if he was merely play-acting the part of emperor. Maximinus claims that his rival lacks a legitimate army, since he only has the support of the young men who had been trained through mock combat. ${ }^{45}$ Maximinus' jeering at Gordian's Carthaginian principate is plainly ironic, while also foreshadowing his own defeat outside Aquileia. Maximinus depreciates Gordian's Carthaginian militia as a force ill-suited to fighting (and for conferring imperial legitimacy). Yet as time would show, it was Maximinus himself who was defeated by a militia force when he invaded Italy. ${ }^{46}$

Gordian does take steps to move beyond the 'pseudo-Rome' of Carthage by gaining authorization for his principate from the senate and people in the sacra urbs itself. He sends letters to noble friends, an official letter to the senate and people, and promises a donativum to the soldiers and a congiarium to the people of Rome. ${ }^{47}$ All these efforts at establishing a legitimate government are undermined by Gordian's lack of control over the army in Africa itself. Since he himself remains in Carthage, then that is where his regime will be won and lost. The author of his demise is Capelianus, the senatorial governor of Numidia and a close adherent of Maximinus. ${ }^{48}$ Gordian had tried

\footnotetext{
${ }^{43}$ Hdn. 7.6.2.

${ }^{44}$ Hdn. 2.8.6, 2.8.9-10, 5.2.4-5; Kemezis 2014, 250-251.

${ }^{45} \mathrm{Hdn}$. 7.8.5. See the important comments of Zimmermann 1999, 275-276.

${ }^{46}$ Hdn. 7.8.5-8.

${ }^{47}$ Hdn. 7.6.3-4.

${ }^{48} \mathrm{Hdn}$. 7.9.1. Capelianus is also cited by name in the HA (Max. 19.1, Gord. 15.1), once again using Herodian as his source, and little else is known about him (Dietz 1980, 109120). On his quashing of the revolt, see Haegemans 2010, 160-164. Capelianus' name is recorded on an epitaph for an African who died fighting on Gordian's side (CIL VIII $2170=I L S$ 8499). Herodian does not develop the fact that a senator was one of Maximinus' staunchest supporters, which goes against the narrative he has constructed of the opposition between the emperor and the senate (see Zimmermann 1999, 264).
} 
to remove Capelianus from office as part of an attempt to enforce his authority, but the Numidian governor retained his position, and more importantly, control of the legio III Augusta and the auxiliary units. ${ }^{49}$ Capelianus' forces, in comparison with the volunteers of Gordian, are composed of battle-hardened troops with experience fighting barbarians. ${ }^{50}$ The inhabitants of Carthage who fight for Gordian's cause prove to be manifestly unsuited for warfare, motivated to take action by their fear and terror rather than any ability or strategic planning, despite being led by Gordian's son. ${ }^{51}$ This rabble seriously compromises the effectiveness of Gordian, a man who traditionally would have seemed to be capax imperii, as Zimmermann has pointed out. ${ }^{52}$

Gordian falls from power, as Maximinus predicted he would in his speech. Gordian does not himself take part in the fighting, but instead remains isolated at his house - just as the hapless Didius Julianus stayed behind on the Palatine when Severus' forces invaded Rome ${ }^{53}$ Herodian claims that Gordian decided to commit suicide because he knew his own forces in Africa could not match those of Maximinus, a potent reminder of the necessity of support from units of the Roman army itself. ${ }^{54}$ The people could help foment revolt and unseat an emperor, but they were in and of themselves insufficient to legitimize his successor, who needed to have the army onside as well. As Whittaker notes, this version of Gordian's death is unique to Herodian, differing from other surviving accounts of the year $238 .{ }^{55}$ This is testament to Herodian's consistency in developing his themes of imperial legitimacy throughout his History, showing how the imperial office depended on negotiating support from the senate, the people and the army, both in Rome and on the frontiers. If one or more of these constituencies was not satisfied, then the emperor would not be successful.

Herodian claims that Gordian 'finished his life as the simulacrum of an emperor'

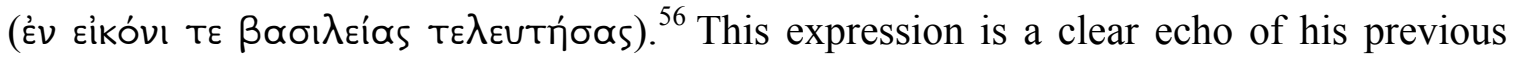

${ }^{49}$ Hdn. 7.9.3.

${ }^{50}$ Hdn. 7.9.1, 3 .

${ }^{51}$ Hdn. 7.9.5-8; Opelt 1998, 2949-50.

${ }^{52}$ Zimmermann 1999, 274-276.

${ }^{53}$ Hdn. 7.9.9. Julianus: Hdn. 2.12.5-7.

${ }^{54}$ Hdn. 7.9.4.

${ }^{55}$ Whittaker 1969-70, 2.217 n. 4.

${ }^{56}$ Hdn. 7.9.10. 
statement that Carthage, Gordian's temporary capital, 'was like a simulacrum of Rome'

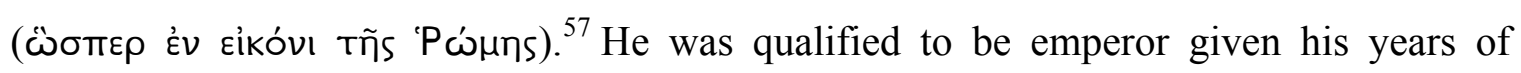
experience as a senatorial administrator, but his regime was hamstrung by his failure to win support from a proper army, and to establish himself in a proper city (Rome) leaving him nothing more than a pseudo-emperor. ${ }^{58}$ As a coda to these events, Herodian has Capelianus consider making a play for the imperial purple himself, if Maximinus' hold on power were to weaken at some point in the future. ${ }^{59}$ This underlines the cyclical nature of imperial power: the fact that Capelianus had the control of the Roman army in Africa leaves open a very real possibility that history will repeat itself. ${ }^{60}$ There would indeed be many pseudo-emperors and pseudo-Romes in Herodian's lifetime and beyond, because in the mid-third century few candidates for the purple would actually succeed in maintaining the right balance between birth, experience, career, and the support of the army, the senate, and the people of Rome. Herodian's exploration of this problem is perhaps his signal contribution to Roman political thought in the third century.

\section{The Speech of Pupienus}

These themes reach their culmination in the speech of M. Clodius Pupienus Maximus, one of the two senatorial emperors of 238, delivered after the siege of Aquileia and the murder of Maximinus and his son. The speech not only punctuates the triumph of the senatorial resistance against Maximinus, it is also the final oration in Herodian's work, and thus deserves special consideration. Pupienus' speech plays a significant role in Herodian's overall narrative design, as it belongs to a select group of speeches and letters in the history which presents a discussion on the nature of kingship. ${ }^{61}$ But as with

\footnotetext{
${ }^{57}$ Hdn. 7.6.2.

${ }^{58} \mathrm{Cf}$. Sidebottom 1998, 2811, who sees his fall as a failure of paideia.

${ }^{59}$ Hdn. 7.9.11.

${ }^{60}$ There was a revolt in Africa under Gordian III, fomented by a certain Sabinianus (Zos. 1.17.1; HA Gord. 23.4-5). Herodian may well have had this in mind when writing this section of the history, though Capelianus and Sabinianus are thought to be separate individuals. On the openness inherent in the ending of Herodian's history, even though it is not unfinished, see the remarks of Zimmermann 1999, 282-283; Hidber 2006, 180.

${ }^{61}$ Zimmermann 1999, 277. For examples, see the speech of Claudius Pompeianus to Commodus (Hdn. 1.6.4-6), and Macrinus' letter to the senate after his acclamation (Hdn.
} 
so many of Herodian's speeches, there is a strong undercurrent of irony, as Zimmermann has noted. ${ }^{62}$ For all that is ostensibly positive about the model of Roman imperial rule projected by the speech and the joint rule of Pupienus and Balbinus, deep contradictions emerge when we consider the oration in the context of the preceding narrative. ${ }^{63}$ Although Pupienus and Balbinus are the sort of men who might be suited to imperial office, as with the previous emperors and pseudo-emperors of Books VII and VIII, their rule is destined to fail because of their inability to balance the demands of emperorship. In this section, we build upon Zimmermann's examination to show how the speech of Pupienus attempts to explain both the confused political situation of 238 and the challenges of the Roman imperial office in the mid-third century.

Pupienus' speech at Aquileia is presented in the narrative context of general rejoicing, as representatives of the Italian cities come to pay tribute to the senatorial emperor. ${ }^{64}$ However, it is crucial that the emperor's oration is addressed not to these gathered municipal dignitaries, but to Maximinus' former soldiers. Pupienus' intention in the speech is to win over the troops, in acknowledgement of the fact that the administration of the empire will only be possible with the assistance and acquiescence of the army. ${ }^{65}$ Ostensibly he should be the best sort of man to deliver the speech, given that in Herodian's idealised formulation, Pupienus is the excellent military commander, while Balbinus is the civilian administrator. ${ }^{66}$ However, Pupienus does little actual soldiering in the History: it is L. Rutilius Pudens Crispinus and Tullius Menophilus, two other

5.1.1-8). Bekker-Nielsen 2014, 243, notes the connections between this speech, Macrinus' letter, and the accession of Severus Alexander in 6.1.1-4.

${ }^{62}$ Zimmermann 1999, 277-281. Bekker-Nielsen 2014, 236-243 offers a complementary analysis of the ways in which the speeches attempt to justify regime change.

${ }^{63}$ Note Sidebottom 1998, 2817: 'the reader is almost always put in a position of knowing more than the characters in the history'.

${ }^{64}$ Hdn. 8.7.1-3.

${ }^{65}$ Hdn. 8.7.4-5. We may note Herodian's overall acceptance of the army's role in the emperor-making process. This is a point of contrast with Cassius Dio, whose view of the army is far more pejorative than that of Herodian, and who believed the army's influence in contemporary politics was thoroughly pernicious: e.g. Cass. Dio 80(80).4.1-2 [Xiphilinus].

${ }^{66} \mathrm{Hdn} .7 .10 .4,7.12 .1$. The idea of Pupienus as the military leader is also found in $H A$ Max. duo 20.4-5; Max. et Balb. 2.7, 5.9, 7.2. This division is accepted by Whittaker, 1969-70, 2.227 n. 2, but Zimmermann 1999, 277 demonstrates that the notion of the military and civilian emperor is idealized. 
senatorial vigintiviri, who oversee the defence of Aquileia. ${ }^{67}$ Indeed, it is Crispinus who is described as an excellent speaker and who delivers an effective oration to the inhabitants of Aquileia persuading them to stand firm. ${ }^{68}$ Herodian's narrative of the siege is told entirely from the perspective of the people of the city and the soldiers themselves, not that of their senatorial commanders. ${ }^{69}$ Pupienus spends the siege at Ravenna, where he is gathering his forces, and it is there that he hears that Maximinus and Maximus have been slaughtered by some of their own troops. ${ }^{70}$ One cannot escape the impression that Pupienus is a somewhat marginalised bystander in these events - there are other senatorial capaces imperii (Crispinus and Menophilus) present at Aquileia; Maximinus' forces are forestalled by the people of Aquileia; and the tyrant is himself murdered by his own troops. ${ }^{71}$ History happens without Pupienus. It is in this incongruous context that Pupienus finds himself addressing Maximinus' former troops, men whom he did not even defeat in battle, and attempting to persuade them of the efficacy of his regime. It is a hard task, given that most of them did not have a hand in Maximinus' death, and were actively hostile to the senatorial emperors. ${ }^{72}$

Pupienus does not seem to acknowledge the situation in quite the way that he should, and immediately he strikes a wrong note, opening his speech by chastising and berating the soldiers. Pupienus informs the troops that they are not in step with 'the

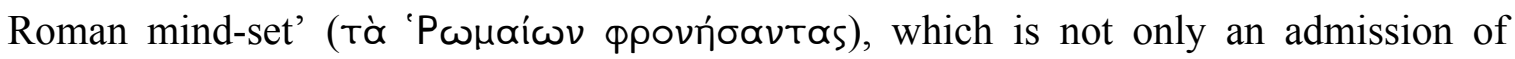
fractured ónóvoı́, but also tacitly implies that they are aliens. ${ }^{73}$ Such an inauspicious beginning to the speech stands in contrast to that given by the young Severus Alexander a similarly unfit military leader, but at least one who tried to identify with the troops by

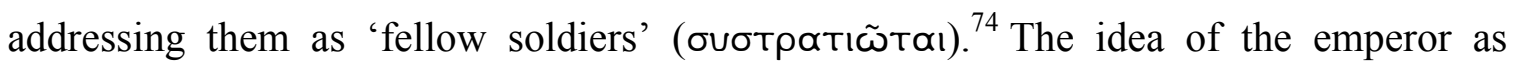

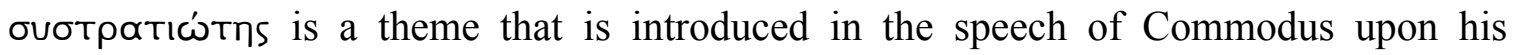

${ }^{67}$ Hdn. 8.2.5. CIL VI 41229 gives Crispinus the title of $d u x$. His praenomen Lucius is now revealed on CIL II.14.2, 992a. For their careers, see Dietz 1980, 210-226, 233-245.

${ }^{68} \mathrm{Hdn}$. 8.3.4-7. This is one of the few speeches in the work which is not incongruous or ironic (Sidebottom 1998, 2817 n. 202).

${ }^{69}$ Hdn. 8.4.1-5.7.

${ }^{70}$ Hdn. 8.6.5; Sidebottom 1998, 2812.

${ }^{71}$ It is interesting that these points are explicitly made in HA Max. et Balb. 12.2-3.

${ }^{72}$ Hdn. 8.7.3.

${ }^{73}$ Hdn. 8.7.4.

${ }^{74}$ Hdn. 6.3.1. 
accession in the first book. ${ }^{75}$ Commodus goes on to explain this term, stating that Marcus always used it to emphasise the idea that 'we all were partners in his virtue' (Tìv $\delta$ '

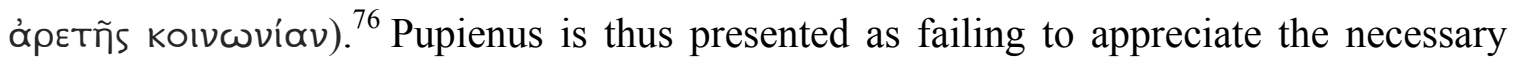
connection between the emperor and the soldiery. He also does nothing to assuage the central point of discontent among the soldiery, namely, the overthrow of their own imperial candidate. He naively assumes that the soldiers will make and keep their military oath to his government, even though these are the same soldiers who broke that oath when they murdered Severus Alexander and his mother Julia Mamaea, and elevated Maximinus to the throne. Given that the preceding books have concentrated on the power of the soldiers to make or break emperors on the Rhine and in Germany, it is alarming that Pupienus disregards their authority in this way. ${ }^{77}$ Thus, Pupienus' government is destined to fail from the beginning, because it lacks the support of one of the key constituencies - the army.

It is in the context of this inauspicious beginning that we must interpret the sentiments that follow, in which Pupienus lays out the benefits of his government with Balbinus. They are ostensibly qualified rulers. In his account of their acclamation, Herodian emphasizes their noble lineages, their maturity, their performance of traditional senatorial offices, and their sober manner of dress. ${ }^{78}$ As members of the ordo amplissimus, elected by the senate itself, the emperors represent the antithesis to tyrannical figures such as the semi-barbaric military pretender, Maximinus, or adolescent aberrations such as Commodus, Elagabalus, or Caracalla, who gained the purple through the lottery of dynastic succession, rather than personal excellence. Pupienus tells the soldiers that he and Balbinus are the most qualified emperors: they were selected by the senate and the people in Rome, on the basis of their nobility and extensive career, as was right and proper. ${ }^{79}$ Yet this is only half true, as Herodian has already told the reader that

\footnotetext{
${ }^{75} \mathrm{Hdn}, 1.5 .3$. This idea is not unique to Herodian, but taps into a commonplace of imperial ideology: Campbell 1984, 32-59.

${ }^{76} \mathrm{Hdn}$. 1.5.3. For the idea that people strive to emulate the behaviour of an emperor, see Hdn. 1.3.4; Men. Rhet. 2.376.

${ }^{77}$ See the comments of Hidber 2006, 176 on how Books VI to VII provide the necessary context for interpreting the resentment of the army towards Pupienus and Balbinus.

${ }^{78} \mathrm{Hdn}$. 7.10.3-4.

${ }^{79}$ Hdn. 8.7.4.
} 
the people were not pleased with the senate's choice of emperors (especially Pupienus), and were ready to kill them both. ${ }^{80}$ It was only on account of the cynical promotion of Gordian III to the rank of Caesar that the people consented to Balbinus and Pupienus' elevation. ${ }^{81}$ The young Caesar, however, is completely absent from Pupienus' speech. ${ }^{82}$ Moreover, when Pupienus refers to his credentials of administrative experience and progression through the cursus honorum, we may recall that it was in Pupienus' tenure as urban prefect that he made himself especially odious to the Roman populace. ${ }^{83}$

Pupienus nevertheless emphasises the importance of the city of Rome in the conferral of imperial legitimacy, remarking that 'the fortune of the kingdom ${ }^{84}$ lies in that

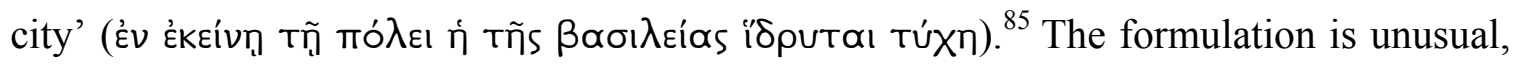
but the context of the passage suggests it means something akin to 'emperors are made at Rome'. The people and the senate in the sacra urbs are the key constituencies which confer legitimacy on the ruler. In the opening book of Herodian's History, the aged senator Claudius Pompeianus makes the point to Commodus that 'Rome is where the emperor is' (í 'P emperor has been properly acclaimed in the first place, with the consensus of the senate, the people, and the army. ${ }^{87}$ In the case of Pupienus and Balbinus, the Roman people had not properly acquiesced. Thus, in Herodian's schema, the senatorial emperors lacked the genuine support of not just the army, but the Roman people as well.

The insecure foundations of the new double principate mean that the potentially successful elements of the emperors' regime are completely undermined. One of the cornerstones of Pupienus' pitch to the soldiers is the notion of dual emperorship, which

${ }^{80} \mathrm{Hdn}$. 7.10.6. On the lack of support for the senatorial emperors from the people, see Marasco 1998, 2867.

${ }^{81}$ Hdn. 7.10.6-9.

${ }^{82}$ Zimmermann 1999, 283 notes the lack of interaction between the senatorial Augusti and Gordian III.

${ }^{83}$ Hdn. 8.7.4. Cf. Hdn. 7.10.6.

${ }^{84}$ Here we may note Tĩs $\beta \alpha \sigma ı \lambda$ eías may be rendered in this context as 'the kingdom', i.e. the Roman Empire, or as the 'institution of the monarchy'.

${ }^{85}$ Hdn. 8.7.5.

${ }^{86}$ Hdn. 1.6.5, with Whittaker 1969-70, 1.32 n.2; Galimberti 2014, 74.

${ }^{87}$ Cf. Ando 2016 on Cassius Dio's conception of imperial legitimacy. He argues that Dio believed that the overall conduct of the emperor was more important than the formal mechanics of his accession. 
he proposes will be a more effective form of imperial rule. He acknowledges that it is an imperial responsibility to keep barbarians in check: with two rulers, one can remain at Rome, and one can campaign on the frontiers. ${ }^{88}$ This is actually a sensible strategy, especially in light of the important role played by the city of Rome and its institutions in conferring legitimacy within Herodian's history at large. ${ }^{89}$ Indeed, the comments seem particularly important and prescient on the part of Herodian, illustrating the push and pull between Rome and the frontiers which all emperors faced, and which were to become more acute as the third century wore on. ${ }^{90}$ Yet, there are still problems with Pupienus and Balbinus' rule. This is not the first time that the concept of joint emperorship is presented in Herodian's History, and previous instances had not been successful. ${ }^{91}$ The idea of joint rule is introduced in the context of Severus' (bogus) offer to share power with Clodius Albinus. ${ }^{92}$ A division of the empire is later proposed as a solution to the discord between the co-Augusti Geta and Caracalla, only for their mother Julia Domna to intercede and state that such a formal separation of territory is impossible. ${ }^{93}$ After the extermination of Geta, Caracalla tells the senators that co-emperors are unnecessary, for even Zeus ruled alone. ${ }^{94}$ Such a sentiment is inherently problematic, coming as it does from a tyrannical emperor, and thus Herodian would not expect his reader to necessarily accept Caracalla's view. Yet history would come to endorse Caracalla's sentiment. In Book V, Herodian presents a grotesque parody of this arrangement of co-emperorship in the context of Elagabalus' adoption of Alexander Severus. Julia Maesa intends for Elagabalus to concern himself with his priestly duties, while Alexander administered the empire. The subtext of this plan is that if one emperor was incompetent or in some way deficient, then

\footnotetext{
${ }^{88} \mathrm{Hdn}$. 8.7.7.

${ }^{89}$ On this relationship between Rome and periphery in Herodian, see Pitcher 2012, 275 277; Kemezis 2014, 240-252.

${ }^{90}$ Davenport 2017, 27-29.

${ }^{91}$ Zimmermann 1999, 278-279.

${ }^{92} \mathrm{Hdn}$. 2.15.3. Severus later repudiates this in a speech to the senate by emphasizing the difficulty shared power: Hdn. 3.6.2.

${ }^{93} \mathrm{Hdn}$. 4.3.8. It is perhaps telling that Herodian does not present the period in which Severus, Caracalla, and later Geta were joint Augusti (198-211) as being one of shared rule. Similarly, there are no retrospective comments about the joint rule of Marcus Aurelius and Lucius Verus (161-169).

${ }^{94}$ Hdn. 4.5.7.
} 
a co-emperor could compensate for this. But human nature trumped political theory, and inevitably discord followed, as we are told Elagabalus immediately began plotting (albeit unsuccessfully) against his adopted son. ${ }^{95}$ The reader of Herodian's work could not fail to remember these problematic instances while reading Pupienus' speech, despite the inherent sensibility of having two emperors to share the burdens of Rome and the frontiers.

Pupienus and Balbinus' joint government fails in practice because of the discord between the two emperors themselves. ${ }^{96}$ Herodian himself offers his own view that this conflict emerged from man's 'desire for monarchia' ( used in the sense of 'sole rule' as opposed to collegiate government. ${ }^{97}$ It was a political commonplace that imperial power could not be divided between equals. ${ }^{98}$ Moreover, neither emperor actually puts the theory of the speech into practice by conducting a campaign. ${ }^{99}$ Instead, Pupienus returns to Rome, where he and Balbinus proceed to quarrel endlessly. Indeed, it is their careers that come between them, as Balbinus argues for primacy based on the fact that he was of noble birth and held a second consulship earlier, while Pupienus highlights his urban prefecture and governorships. The grounds for conflict are plausible, and the discussion shows an unusual degree of insight into aristocratic competition on Herodian's part, as Dietz has argued. ${ }^{100}$ Rivalries between senators for honours such as iterated consulships are demonstrated by documents such as the 'Glass Ball Game' inscription. ${ }^{101}$ The fact that Pupienus always comes first in their joint imperial titulature, despite Balbinus holding his second consulship over twenty

\footnotetext{
${ }^{95} \operatorname{Hdn} .5 .8 .2-8$.

${ }^{96}$ Hdn. 8.8.4-5; Zimmermann 1999, 281; Bekker-Nielsen 2014, 244. Dietz 1976 argues for the historical authenticity of Herodian's interpretation of the emperors' rivalry.

${ }^{97}$ Dietz 1976, 384.

${ }^{98} \mathrm{Hdn}$. 8.8.4. For the commonplace, note Cass. Dio F 7.3, although it is perhaps ultimately Thucydidean.

${ }^{99}$ The putative Parthian and German campaigns in the $H A$ are most probably fictitious (HA Max. et Balb. 13.5). Haegemans 2010, 228-229 suggests the production of civic coinage in the east could suggest preparations for a war against Persia.

${ }^{100}$ Dietz 1976. The HA Max. et Balb. 14.1 offers different reasons for tension: Pupienus' apparent humble birth, and Balbinus' feeble nature.

${ }^{101}$ Champlin 1985, 159-163.
} 
years earlier, indicates some form of negotiation and compromise in this area. ${ }^{102}$ In their official position and public image, the emperors were portrayed as equals, even jointly holding the post of pontifex maximus, the first emperors to share the office. ${ }^{103}$ The tension between Pupienus and Balbinus represents a failure of collegiate government of senators, who were chosen on account of their nobility and cursus, rather than on the dynastic principle. ${ }^{104}$ It is telling that such a non-dynastic experiment in joint rule would not be repeated again in Herodian's lifetime, until reformulated on the basis of different criteria by Diocletian.

The fact that Herodian raises the issue of dual emperorship and considers how such an imperial college could function is important in and of itself. Imperial colleges composed of two Augusti had become more common since the late second century. The paradigm for such co-emperorship was the joint rule of Marcus Aurelius and Lucius Verus, and had since been followed by Marcus Aurelius and Commodus; Septimius Severus and Caracalla; Septimius Severus, Caracalla, and Geta; and more briefly, Caracalla and Geta. In all cases, one Augustus was senior to his colleague in that he alone held the title of pontifex maximus. ${ }^{105}$ There were also differences in familial relationships and age that gave each of these colleges their own particular qualities. There appears to have been little attempt to fashion a political philosophy of multiple emperorship beyond the strictly dynastic. ${ }^{106} \mathrm{~A}$ rare example can be found in Xiphilinus' Epitome of Cassius Dio's Roman History, in which the philosopher Marcus, frail and unsuited for warfare, is said to have selected Verus as co-emperor as he was much younger and therefore suited

${ }^{102}$ Balbinus was cos. II ord. 213, Pupienus cos. II ord. 234 (Kienast 2011, 191, 193). Dietz 1976, 422-424 suggests that it was the prefecture of the city which gave Pupienus priority.

${ }^{103}$ For their public image, see Dietz 1976, 385-391; Haegemans 2010, 174-179. On the pontificate, see HA Max. et Balb. 8.1, supported by inscriptional evidence (e.g. CIL VIII 10342; $A E$ 1993, 1778).

${ }^{104}$ Marasco 1996, 2861-2862 points out how the rivalry between the senatorial emperors disrupts the harmony of the state and its constituent elements.

${ }^{105}$ Marcus Aurelius, Septimius Severus, and Caracalla (Kienast 2011, 137-138, 156-157, 162-163).

${ }^{106}$ For Marcus and Commodus, see references in Davenport and Mallan 2014: 657. 
for warfare ${ }^{107}$ Although it is clear that Cassius Dio had firm views on the incompatibility of dual emperorship with human nature, it is unfortunate that the remaining portions of Dio's imperial narrative do not allow us to appreciate what his views were on experiments in imperial collegiate government - namely those of Marcus and Verus, and Severus and Caracalla. Herodian adopts a different perspective, regarding dual emperorship as a topic worthy of sustained discussion, hence the recurrence of the theme throughout the history, culminating in the speech of Pupienus. His narrative shows us that although it was a good idea in theory, power sharing was fundamentally impracticable because of individual rivalry and ambition. It is telling that in Herodian's opening panegyric of Marcus Aurelius as the ideal emperor, there is no reference to the years of joint rule with Lucius Verus.

The sentiments of Pupienus' speech are thus undermined and exposed as being problematic by the events of Herodian's History itself. It is unsurprising that the soldiers he is addressing are unconvinced, despite his generous promise of an amnesty in return for their allegiance. ${ }^{108}$ This, Herodian says, is because the army disliked having their emperors selected by the senate. ${ }^{109}$ The brutal and uncompromising murder of Pupienus and Balbinus by the praetorians justifies Herodian's interpretation of the situation. But it certainly leaves one wondering what the author's intentions are. Our historian clearly does not advocate the acclamation of a soldier emperor such as Maximinus, the archetypical tyrant, as the right course of action for the imperium Romanum in the third century. ${ }^{110}$ Yet at the same time, he has misgivings about relying on nobility to produce a leader - the disastrous rise and fall of Magnus, Quartinus, and Gordian I demonstrate

${ }^{107}$ [Dio Cass.] 71.1.1 ${ }^{2}-3=$ Xiph. 258.10-23. It is doubtful whether these sentiments can actually be attributed to Cassius Dio himself. Boissevain correctly saw this passage as not being drawn from Dio's history, but from a subsidiary source, given the loss of Dio's account of the reign of Antoninus Pius and the first part of Marcus and Verus' reign. Cf. [Dio Cass.] 70.1.1 = Xiph. 256.8-12: Boissevain 1955, 3.246; Juntunen 2013.

${ }^{108}$ Hdn. 8.7.2.

${ }^{109}$ Hdn. 8.8.2.

${ }^{110}$ pace Alföldy 1974, 95: 'Herodian left no doubt about his opinion that the restoration of the Antonine type of monarchy was no longer possible, because only hard soldieremperors, with the aid of the armies, were still able to hold the empire together and to defend it against the barbarians.' 
this. ${ }^{111}$ Zimmermann has argued that Herodian advocates an emperor whose career and actions demonstrated their suitability for the purple, not their birth. ${ }^{112}$ Pupienus might qualify on these grounds (at least as he is characterised in the text), but Balbinus does not. In the end, the human flaws in their joint emperorship undermine even sound strategic notions such as the separation of powers between two emperors, one based in Rome and another on the frontiers. The point of Pupienus' speech is to reveal not only the reasons why the regime of the senatorial emperors failed, but also to lay bare the tension in the competing demands placed on Roman emperors in the mid-third century; specifically, the importance of having the support of all constituencies of the state, which, in Herodian's view, has not prevailed since Marcus' reign.

\section{Conclusion}

Herodian does not push his analysis of the imperial malaise to great lengths there is no extended disquisition or ruminations on the nature of imperial office that we might find in a sophisticated work of political philosophy, or even in the work of a historian like Cassius Dio. Herodian's history is about diagnosing problems rather than offering solutions to the issue of the imperial succession. As we have seen, Herodian's narrative world is one where there are no real surprises. Historical causation operates with clockwork regularity. Through various narrative devices, Herodian is able to foreshadow the collapse of regimes almost from the point of their inception. The

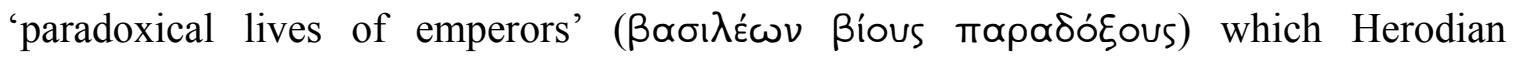
mentions at the outset of his work are in fact not paradoxes at all, but are lives which follow an all too predictable trajectory, destined to fail.

The final two books of Herodian's history offer an important reading of the crises of the mid-230s. Nowhere do we see Herodian the political diagnostician in clearer light.

${ }^{111}$ On the failings of patricians in Herodian's work, see Sidebottom 1998, 2794-2795.

112 Zimmermann 1999, 278. Cf. Dietz 1976, 401-402. Note too, Macrinus' letter to the Senate (Hdn. 5.1.2-8, esp. 5-7) where he argues against the notion that nobility is enough to ensure a good ruler. As with so many of the speeches or letters in Herodian's work, there is a degree of irony here. Nobility may not be sufficient to ensure good leadership, but the low-born yet industrious Macrinus is certainly not a good ruler in Herodian's eyes (Hdn. 5.4.12). 
The catalogue of emperors and pseudo-emperors in Books VII-VIII highlights the near impossible predicament faced by Roman emperors acclaimed at the frontiers. Herodian's thought-world is in many ways inherently conservative and Italo-centric: emperors are supposed to travel to Rome to ensure that their government is properly ratified. 'Little Romes', such as those created by Gordian I in Carthage, are mere shadows of the sacra urbs and the constitutional legitimacy it offered. Of course, as Herodian well knew, it was now expected that emperors be present on the frontiers in person to prosecute wars against Rome's enemies. In his view, the only way to administer the government effectively from the periphery was with the support of senatorial advisors and an effective army, just like Marcus Aurelius. This required deep and broad consensus. The failure to secure the allegiance of one of these constituencies (particularly the army) could, and did, lead to usurpation and the proclamation of rival emperors. It is one of the important features of Herodian's narrative that he underscores the difficult predicament faced by these would-be principes - often proclaimed at the point of a sword by rebellious troops, they had little choice but to acquiesce. The downfalls of claimants such as Quartinus, Macedo, and Gordian I have a certain tragic quality about them. In this world, even noble birth or a stellar senatorial career could not guarantee that a candidate would become a successful emperor. Herodian's narrative of the 230s therefore reveals that he was an historian whose thinking was in some ways very traditional, but who was nevertheless aware of contemporary realities.

The political programme outlined by Pupienus in his speech to the soldiers after the siege of Aquileia seems on first sight to offer a solution to this quandary. There are now two emperors, Pupienus tells the troops, with experience in civilian and military affairs, who can ensure that both Rome and its frontiers are safeguarded. Yet Herodian undercuts the seemingly ingenious and pragmatic solution of dual emperorship both in his wider narrative, in which collegiate governments end in failure, and through his depiction of the rivalry of Pupienus and his co-emperor Balbinus themselves. Indeed, the narrative of Book VIII shows that the two senatorial emperors lacked the support of the army and a broad consensus on which to found a successful government like that of Marcus Aurelius. 
There is much that is conservative and traditional about Herodian's views on the Roman state and the place of the emperor in this world. Prima facie, Herodian's language, and his invocation of Eúvora and ónóvora recalls that of Dio of Prusa and Aelius Aristides. Yet unlike his second century precursors, he applies this to the constitutional elements of the Roman state, rather than to the cities of the empire. He is thus closer in spirt to Cassius Dio than Dio of Prusa. ${ }^{113}$ In this vein, Herodian stands towards one end of a long tradition that represented the Roman politeia as a mixed constitution. But unlike Polybius, or Aelius Aristides, Herodian's history was of a politeia that no longer functioned as it should. The ideal mixed-constitution was one where the balance of its constituent parts ensured that the state never descended into the tyranny, petty oligarchy, or ochlocracy. The critical absence of Eüvoı and ómóvoı between the key constituents of Herodian's Roman politeia - the senate, the people, the army (not to mention imperial colleagues) - ensured that the lives of the emperors following Marcus Aurelius would usually be nasty, brutish, and short. Herodian's emperors fail to live up to the example of Marcus not because they are essentially all bad men (like Maximinus), but rather because they are unable to balance the interests and demands of the three orders of the Roman state. ${ }^{114}$ Herodian's History may not offer concrete solutions to these problems of empire and emperorship, or how the broken politeia could be restored. Nevertheless, what he does offer is an explanation to the question he poses at the beginning of his work - why so many emperors rose and fell over the course of so few years.

A final question remains. What impact does the elevation of Gordian III have on this narrative? ${ }^{115}$ One thing is certain, from what Herodian says about the failures of earlier emperors: the accession of the young ruler would not be the panacea to alleviate the ills afflicting the Roman empire. If the work were written under that adolescent emperor, no reader could fail to see the implications of Herodian's analysis for their

\footnotetext{
${ }^{113}$ For ópóvoı a and the State in Cassius Dio, note Cass. Dio F 52.1; cf. 44.2.4-5.

${ }^{114}$ In this way, Herodian anticipates the analysis of some modern historians of the crisis of the 230s, such as Potter 2013, 169-170.

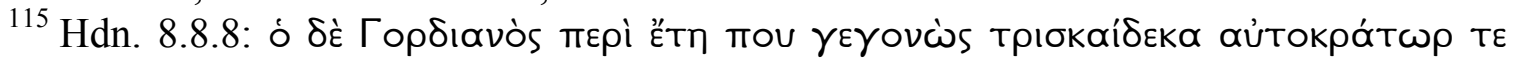

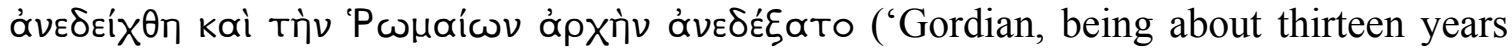
old, was acclaimed imperator and received the Roman empire').
} 
contemporary situation. ${ }^{116}$ If it were written in the aftermath of that short-lived regime, then readers would have a ready-made explanation for why yet another emperor fell. ${ }^{117}$

\section{Bibliography}

Alföldy, G. (1971a). Herodians Person. Ancient Society 2, pp. 218-19.

Alföldy, G. (1971b). Zeitgeschichte und Krisenempfindung bei Herodian. Hermes 99, pp. 429-449.

Alföldy, G. (1974). The Crisis of the Third Century as seen by its Contemporaries. GRBS 15 , pp. 89-111.

Ando, C. (2016). Cassius Dio on Imperial Legitimacy, from the Antonines to the Severans. In: V. Fromentin, E. Bertrand, M. Coltelloni-Trannoy, M. Molin, and G. Urso, eds., Cassius Dion: nouvelles lectures, Bordeaux, pp. 567-577.

Barker, E. (1956). From Alexander to Constantine: Passages and Documents illustrating Social and Political Ideas. Oxford.

Bekker-Nielsen, T. (2014). Herodian on Greek and Roman Failings. In: J.M. Madsen and R. Rees, eds., Roman Rule in Greek and Latin Writing: Double Vision, Leiden, pp. 224245.

Birley, A. R. (2005). The Roman Government of Britain. Oxford.

Boissevain, U. P. ed. (1955). Cassii Dionis Cocceiani Historiarum Romanarum quae supersunt. Berlin.

Campbell, J. B. (1984). The Emperor and the Roman Army. Oxford.

Champlin, E. (1985). The Glass Ball Game. ZPE 60, pp.159-163.

Davenport, C. (2017). Rome and the Rhythms of Imperial Life from the Antonines to Constantine. Antiquité Tardive 25, pp. 23-39.

Davenport C., and Mallan, C. (2014). Hadrian's Adoption Speech in Cassius Dio's Roman History and the Problems of Imperial Succession. AJPh 135, pp. 637-668.

De Blois, L. (1998). Emperor and Empire in the Works of Greek-Speaking Authors of the Third Century A.D. $A N R W 2.34 .4$, pp. 3391-3443.

${ }^{116}$ For the dates of the work, cf. footnote 1, above.

${ }^{117} \mathrm{We}$ are very grateful to the journal's anonymous referees for their thoughtful comments on this article. 


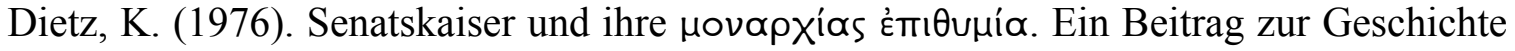
des Jahres 238 n. Chr. Chiron 6, pp. 381-425.

Dietz, K. (1980). Senatus contra principem. Untersuchungen zur senatorischen Opposition gegen Kaiser Maximinus Thrax. Munich.

Galimberti, A. (2014). Erodiano e Commodo. Traduzione e comment storico al primo libro della Storia dell'Impero dopo Marco. Göttingen.

Grasby, K. D. (1975). The Age, Ancestry, and Career of Gordian I. CQ 25, pp. 123-130.

Haegemans, K. (2010). Imperial Authority and Dissent: the Roman Empire in AD 235238. Leuven.

Heil, M. (2006). 'Soldatenkaiser' als Epochenbegriff. In: K. P. Johne, T. Gerhardt, and U. Hartmann, eds., Deleto paene imperio Romano: Transformationsprozesse des Römischen Reiches im 3. Jahrhundert und ihre Rezeption in der Neuzeit, Stuttgart, pp. 411-428.

Hidber, T. (2004). Herodian. In: I. J. F. de Jong, I. Nunlist, and A. Bowie, eds., Narrators, Narratees, and Narratives in Ancient Greek Literature: Studies in Ancient Greek Literature, Leiden, pp. 201-210.

Hidber, T. (2006). Herodians Darstellung der Kaisergeschichte nach Marc Aurel. Basel.

Juntunen, K. (2013). The Lost Books of Cassius Dio. Chiron 43, pp. 459-486.

Kaldellis, A. (2017). How Perilous was it to Write Political History in Late Antiquity? Studies in Late Antiquity 1.1, pp. 38-64.

Kemezis, A. M. (2014). Greek Narratives of the Roman Empire under the Severans. Cambridge.

Kienast, D. (2011). Römische Kaisertabelle. Darmstadt.

Kuhn-Chen, B. (2002). Geschichtskonzeptionen griechischer Historiker im 2. und 3. Jahrhundert n. Chr.: Untersuchungen zu den Werken von Appian, Cassius Dio und Herodian. Frankfurt.

Laes, C. and Strubbe, J. H. M. (2014). Youth in the Roman Empire: The Young and Restless Years? Cambridge.

Lotz, J. P. (2007). Ignatius and Concord: The Background and Use of the Language of Concord in the Letters of Ignatius of Antioch. New York.

Lucarini, C. M., ed. (2005). Herodianus Regnum post Marcum. Leipzig. 
Marasco, G. (1998). Erodiano e la crisi dell'impero. $A N R W$ 2.34.4, pp. 2837-2927.

Martin, J.-P. (2006). L'image de Maximin le Thrace dans Hérodien. In: M.-H. Quet, ed., La 'Crise' de l'Empire Romain de Marc Aurèle à Constantin: mutations, continuités, ruptures. Paris, pp. 95-106.

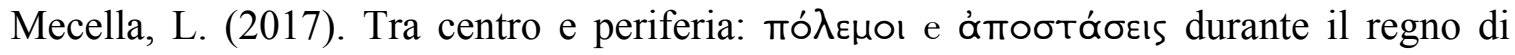
Massimino Trace. In: A. Galimberti, ed., Erodiano: tra crisi e trasformazione. Milan, pp. 187-214.

Opelt, I. (1998). Furcht und Schrecken bei Herodian. ANRW 2.34.4, pp. 2928-2952.

Pitcher, L. V. (2012). Herodian. In: I. J. F. de Jong, ed., Space in Ancient Greek Literature. Leiden, pp. 269-282.

Polley, A. R. (2003). The Date of Herodian's History. AC 72, pp. 203-208.

Potter, D. S. (2013). The Roman Empire at Bay, AD 180-395. London.

Sidebottom, H. (1997). The Date of the Composition of Herodian's History. AC 66, pp. 271-276.

Sidebottom, H. (1998). Herodian's Historical Methods and Understanding of History. ANRW 2.34.4, pp. 2775-2836.

Syme, R. (1971). Emperors and Biography: Studies in the Historia Augusta. Oxford.

Syme, R. (1983). Emperors from Etruria. BHAC 1979/1981, pp. 333-360.

Townsend, P. W. (1955). The Revolution of A.D. 238: The Leaders and their Aims. YCS 14, pp. 49-105.

Whittaker, C. R., ed. and trans. (1969-70). Herodian. History of the Empire. 2 vols. London and Cambridge, MA.

Zimmermann, M. (1999). Kaiser und Ereignis: Studien zum Geschichtswerk Herodians. Munich. 